\title{
Secrecy, Sacrifice, and God on the Island: \\ Christianity and Colonialism in Coetzee's Foe and Defoe's Robinson Crusoe
}

\author{
Jay Rajiva
}

$J_{\text {con }}$

M. Coetzee's novel Foe begins with a shipwreck and ends with a confrontation underwater, as an unnamed, previously unvoiced narrator encounters Friday in a place "where bodies are their own signs" and each spoken word "is caught and filled with water and diffused" (Coetzee 1986, 157). ${ }^{1}$ In this confrontation, Coetzee also withholds Friday from the reader's understanding, securing his body, as Gayatri Spivak notes, in "the real margin that has been haunting the text since its first page" $(1999,186)$. Thus Friday gestures only as that which will always keep its silence within the dominant colonial and historical register: we never receive any specific indication of what Friday might be, except a symbol of the breakdown of meaning. Friday is mute, intractable, mysterious, yet linked to the inexpressible "sounds of the island" (F 154). I argue that the tension in Coetzee's repetition of Daniel Defoe's Robinson Crusoe springs from the exposure of the Christian secret in both the colonial enterprises of the characters and the authorial presences of Defoe and Coetzee. My argument draws on Jacques Derrida's characterization of Christianity in The Gift of Death, which outlines how Christianity incorporates (but does not destroy) older, non-Christian elements into its own epistemic framework without acknowledging this act of incorporation. In Defoe's novel, Crusoe, the white colonial explorer, explicitly sets out to convert Friday to Christianity and succeeds in that goal through the triumph of Christian tenets: devotion to God requires the keeping of an absolute secret, a willingness to sacrifice, and prostration before the gaze of God, at whom, because God is always what exceeds one's understanding, one can never gaze back. Friday and Crusoe's discussion about the worship 
Jay Rajiva

of God offers a startling if inadvertent subversion of the Christian subject position in Defoe's novel. And the nonpresence of Friday in Foe widens this subversion, revealing the work of colonial Christianity as still in transition, convulsed by the repetition of what it is attempting to subordinate in secret: the non-Christian other whose sacrifice cannot be openly acknowledged. I suggest that what Foe accomplishes, as a literary response to Robinson Crusoe, is to expose this secret as secret, to lay bare the religious economy of sacrifice on which the colonial enterprise has historically rested.

The vexed relationship of Foe to the ethics of representation has been well-documented. For Michael Marais, "Cruso's authorial imperialism . . . is informed by the hermeneutic urge to domesticate both Friday and the alien landscape of the island by integrating both into a European system of recognition" (1996, 69), while Teresa Dovey observes that in Foe "the colonised subject has no discursive authority within the field of western discourses" (1998, 26). Derek Attridge (2004) writes of the relationship between Derridean ethics and Coetzee's fiction in terms of his commitment to the radical alterity of the other's voice, both as a textual impossibility and as the precondition for any kind of ethical exchange. Spivak, in her turn, focuses on the implication of Western feminism in the capitalist-driven colonial framework within which Friday is "the unemphatic agent of withholding in the text" $(1999,190)$.Valuable as these readings are, they tend to treat Christianity as the historical accompaniment to the novel's representation of colonialism, rather than as a vital part of how the process of colonial incorporation is staged. What this essay will demonstrate is the way Foe uses the mechanics of stalled repetition and secrecy to characterize colonialism as a hegemonic framework both constituted by and constitutive of Christian ethics. In Doubling the Point, Coetzee is clearly uncomfortable with David Attwell's suggestion that his writing has moved closer to an implicitly Christian notion of grace: "As for grace, no, regrettably no: I am not a Christian, or not yet" (Coetzee 1992a, 250). Even so, as Patrick Hayes has noted, Coetzee does seem concerned with "a debate of fundamental importance between 'cynicism' and 'grace," where cynicism is "the denial of any ultimate base for values" and grace is "a condition in which truth can be told clearly, without blindness" $(2006,275)$. Indeed, Hayes locates the turn from cynicism to grace as a watershed moment for Coetzee, whose later work (notably Age of Iron [1990], The Master of Petersburg [1994], and Disgrace [1999]) pits the endlessly self-serving individuality of cynicism against the struggle, however blind or obdurate, for some notion of earthly 
salvation. ${ }^{2}$ Within this framework, Friday's body, like the "earlier" version of Defoe's Friday, becomes visible as the implicit target of conversion; as it becomes visible, it allows the novel to expose exploitation as the heart of a specifically Christian colonial project.

Linda Hutcheon (1988) has characterized Foe as an example of historiographic metafiction: postmodern writing that interfaces with and contests specific historical moments within an intensely self-reflexive formal framework, calling attention to the fissures and instabilities of history as a branch of knowledge. ${ }^{3}$ Historiographic metafiction, Hutcheon argues, "rejects projecting present beliefs and standards onto the past and asserts, in strong terms, the specificity and particularity of the individual past event," acknowledging "that we are epistemologically limited in our ability to know the past, since we are both spectators of and actors in the historical process" $(1988,122)$. Historical details are thus frequently "falsified in order to foreground the possible mnemonic failures of recorded history," thereby dramatizing the "process of attempting to assimilate" (114) rather than focusing on the end result. Drawing on Hutcheon, I extend the critical discussion of Coetzee's oeuvre by locating in Foe a structural relation to Derrida, one that attends to the relationship between the assimilative process of Christian conversion and the ethics of narrative. In recasting Defoe's story of the colonial explorer as anticolonial metafiction, I argue that Foe creates a tacit but insistent Christian subtext of failed repetition that binds the two stories together. Within a Derridean framework, imaginative repetition in the novel discloses itself as a task beset by failures it can never acknowledge in a Christian context. In enacting these failures of repetition, Foe dramatizes the epistemic limit of the colonist as a specifically Christian limit, illustrating the extent to which each framework subtends and informs the other.

\section{Repetition and incorporation}

My readings of Robinson Crusoe and Foe depend upon Derrida's exegesis of the development of Christianity in The Gift of Death. There Derrida consolidates this development into three sequential phases: demonic (orgiastic) irresponsibility, Platonic (ethical) responsibility, and, finally, Christian conscience or the mysterium tremendum (trembling mystery). The origin of the demonic lies precisely in the absence of responsibility: one has no obligation to respond to the other, to seek recognition in the face of the other, or to justify oneself before another, free to satisfy an internal drive that envelops one in interiority. The demonic thus involves 
Jay Rajiva

secrecy, disdaining to elaborate or disclose itself. Identifying the demonic as that which "crosses the boundaries separating the human, the animal, and the divine" $(1995,3)$, Derrida discusses the attempt to historicize this question of secrecy in relation to the birth of "modern" Europe. We can thus make the tacit link from the demonic to paganism, mysticism, totemism, and cannibalism: to everything beyond the pale of Christianity at its formation.

Plato attempts to break with demonic secrecy by turning the self away from irresponsibility toward "the Good and the intelligible sun, out of the cavern" (7), forsaking the dark secrecy of the cavern for the sunlight of full disclosure. However, in rendering this turn as progress toward a "new mystery of the soul," and in ignoring its specific historical (European) context, Platonic responsibility never truly breaks with demonic mystery; rather, it holds it in hiding, asking us to keep two secrets, two mysteries of erasure (8). Though Derrida does not stress the point, to my mind this passage from demonic to Platonic is a re-creation: the demonic is not destroyed but instead persists in the form of a repetition whose disembodied possibility sets the ethical limit for the Platonic subject.

In the final phase, Platonic responsibility gives way to a Christianity that supplants the light of the Good with that of God, binding one to a relation with a wholly other whose gaze penetrates to one's very soul. God demands that one give everything to him without knowing in advance what the result may be; one's sense of responsibility is now permanently lodged in a devotion to God. But in order to elevate "the natural foundation" (Derrida 1995, 24) of Christian theology, this passage into Christianity surreptitiously relies on Platonic rationalism, thereby deprioritizing responsibility in and of itself. Furthermore, while responsibility of necessity must entail a recognition of what it means to be responsible, this responsibility is, according to Derrida, never sufficiently theorized in Christian theology. We are left, that is, with an irresponsible (because incomplete) definition of responsibility, which remains opaque and thus maintains a tacit connection to the irresponsibility of demonic mystery: another repetition and another secret.

Just as this tacit connection inhabits Christian theology, it has ramifications for attempts to work through Christian origins in the ethical register. In Moses and Monotheism, Freud characterizes the association of the demonic with the pagan (non-Christian) as a teleology: totemism, the mystical worship of and identification with a strong animal, gives way to cannibalism, as the strong sons kill and devour the father, in turn 
acceding to the worship of human gods, as polytheism, and finally to monotheism in the forms of Judaism and, subsequently, Christianity. ${ }^{4}$ That Freud acknowledges he has little or no historical basis for this formulation dovetails with Derrida's positing of this tradition as specifically European: the non-European other becomes the locus of that which exceeds the parameters of Western psychoanalytic discourse. Freud's dismissal of the need for evidence, or for logic, demonstrates the construction of the European Christian self as a process whose urgency overrides the historical specificity of what it is attempting to contain and sublate. Talal Asad sees the development of modern Christian doctrine, for example, as tacitly relying on Enlightenment reason, which creates issues of "translation" when Western anthropologists attempt to study nonChristian religions such as Islam $(1993,2)$. Such quandaries call attention to the forms that disavowed repetition (incorporation) can take even within disciplines such as psychoanalysis, anthropology, and philosophy that seek to account for the givenness of origins.

For Derrida, Christianity is driven to incorporate the demonic and the Platonic into itself and then to erase all traces of that process. In this, he himself partly repeats Asad's interrogation of Christianity's turn toward secrecy and interiority, which, for Asad, is the Kantian "construction of [Christianity] as a new historical object: anchored in personal experience, expressible as belief-statements, dependent on private institutions, and practiced in one's spare time" $(1993,207)$. However, the incorporated trace is, for Derrida, always visible by virtue of the contradictions and slippages by which the older systems of knowledge are subsumed. Literature, in its turn, dramatizes the difficulty by which branches of knowledge negotiate the givenness of their own founding principles. To the extent that Foe is an intertextual repetition of Robinson Crusoe, both works represent a silence: requiring nonreciprocal sacrifice to God, faith is irreducibly secret and never open to repetition, but the hidden incorporation of older demonic and Platonic elements becomes a stalled repetition that haunts the problem of conceiving ethical responsibility to the human. Foe, I argue, exposes the incorporative process by linking the colonial project to a historically contingent Christianity. I will stage this argument by examining the conversion of Friday in both Robinson Crusoe and Foe, characterizing him as the element that resists "proper" integration into the European ethico-religious system of both novels. Friday's refusal to be legibly coded is not merely a refusal of colonial hegemony but a challenge to the Christian ethic of asymmetrical and secret sacrifice. 
Jay Rajiva

\section{Crusoe and Friday}

In Defoe's Robinson Crusoe, the connection between intratextual repetition and the disavowed repetition within Christianity emerges in Crusoe's failure to acknowledge the symbolic and moral significance of the events leading up to his shipwreck on the island. Twice over or more, Crusoe is shipwrecked, repents, ignores the signs of fate, suffers a setback due to a violent and unexpected storm, debates over whether to kill a cannibal (or cannibals), and quells all doubt with the pleasures of the flesh. He rejects his father's warning that he will suffer the same fate as his older brother ${ }^{5}$ if he ventures into "miseries which Nature and the station of life [he] was born in seemed to have provided against" (RC 3). ${ }^{6} \mathrm{He}$ boards the ship that eventually shipwrecks on the island on the same day he first sets out from his parents' home, finds the same barley growing on the island as in England, and even re-narrates the events of his shipwreck in his journal. At first, as in the instances above, Crusoe spurns any inclination toward the Christian devotion that eludes mortal understanding, in favor of either rationalism (the barley had been accidentally cast ashore from the shipwreck) or irresponsibility (banishing his hesitation through drink). At this point, he is "thoughtless of a God or a Providence," acting "like a brute from the principles of Nature" (68). It is only with the onset of illness, imposing on him solitary reflection, that he is prompted to recognize that Providence "knows that I am here, and am in this dreadful condition" (70). Through this recognition, Crusoe gradually becomes secure in his faith, not merely resigning himself to God's will in his continued isolation on the island but "even to a sincere thankfulness" (101) for that isolation.

However, Crusoe's discovery of Friday on the island opens up a space of tension through a remarkable exchange between them about religion, God, and the devil, in the context of Crusoe's attempt to convert Friday to Christianity. I am not particularly concerned with treating Crusoe as an exemplar of formal realism's encapsulation of the individual, ${ }^{7}$ nor do I wish to discuss the impact of "colonial setting" on "Crusoe's individualism ... in a world in which he is surrounded by religious and cultural Others" (Mcinelly 2003, 2). I want to read this attempt in order to illustrate how Defoe's text creates the discursive possibility of resistance within Christianity's very terms, setting the stage for Coetzee's Foe to critique the incorporative, interpenetrating processes of both colonialism and Christianity. Initially, Crusoe strives to distinguish God from Benamuckee, but he is forced into a tautology: worship God because he is superior, but he is superior only because Crusoe compels Friday to worship him. Musing that "the policy of making a secret religion in 
order to preserve the veneration of the people" can perhaps be found in "all religions in the world" ( $R C$ 166), Crusoe, despite his intentions, exposes the constructedness of Christianity's claim to colonial authority: the secrecy of one's connection to God is by definition unverifiable and is the basis for any religion, not merely for Christianity. As quickly as he introduces this possibility, however, Crusoe drops it, insisting on a spatioethical contrast between Benamuckee, who can only be worshipped on mountaintops, and God, who is able to receive prayers from anywhere, in secret, in one's own heart (evidenced by Crusoe's many private "conversations" with God before he encounters Friday). While the pagan god is spatially bound, the Christian God is unseen but omnipresent, and when Friday reveals that Benamuckee's priests communicate his word to the people, Crusoe denounces their behavior as a "fraud" and a "cheat" (167). God becomes the foundation of natural law, a rational a priori demanding responsibility even as it obscures the origins of such a demand.

The arbitrariness of such origins nonetheless emerges, however, in Crusoe's discussion of the devil: "I entered into a long discourse with him about the devil . . . his setting himself up in the dark parts of the world to be worshipped instead of God, and as God, and the many stratagems he made use of to delude mankind to their ruin; how he had a secret access to our passions and to our affections; to adapt his snares so to our temptations." Now it is the devil who works in "secret." If the devil has "secret access" to innermost souls, however, what prevents him from being God in another guise? What distinguishes God from the devil? Against his aims, Crusoe has thus positioned the devil as an imaginative repetition of God, and himself (the voice of another) as the messenger of a God who may be the devil. Arguing that Defoe stages these conversion scenes to demonstrate "the need for evangelism of a fairly sophisticated kind" in order to recruit converts to Christianity, Timothy Blackburn illustrates the tendency in Defoe scholarship to instrumentalize Friday's conversion, showing how the uncertainty of the Christian ethic is quickly subsumed to the exigencies of colonialism $(1985,373) .{ }^{8}$ In other words, while Crusoe may well need a more "sophisticated" theoretical framework in order to be more convincing as a missionary, his failure here also opens up a space of anticolonial resistance for Friday that the novel cannot resolve except by ad hoc closure.

Faced with a colonial subject who will not readily keep the secret by accepting God as the foundation of natural law, Crusoe speaks an original repetition by which he is the messenger of God but also, like Benamuckee's priests as he understands them, the emissary of the devil. 
Jay Rajiva

Such unstable speech, born of the other's refusal to accept the givenness of Christianity, evokes Derrida's critique of Austinian speech act theory: "Does the quality of risk," he asks, "surround language like a kind of ditch or external place of perdition which speech could never hope to leave, but which it can escape by remaining 'at home,' by and in itself, in the shelter of its essence or telos?" $(1988,17)$. For Derrida, there is no staying "at home" for language, because establishing that prior place of safety is itself of necessity a linguistic process. The condition of undecidability, once acknowledged, is not easily dispensed with, as Friday, when told that God is undoubtedly stronger than the devil, wonders why God does not simply kill the devil and be done with the matter. To this Crusoe has no response except the hasty temporization that God will eventually punish the devil, which rather than settling the question simply prompts Friday to renew it, as he reasonably then wonders why God does not strike the devil down right now, before he can do any more harm. Crusoe finally asserts that God gives all beings, even the devil, time in which to repent and be forgiven, to which Friday, in a masterful counterstroke, replies: "That well; so you, I, devil, all wicked, all preserve, repent, God pardon all" (RC 168). Friday has thus exposed the contradiction in Christian moral law, that God and the devil, ostensibly opposed beings, are revealed as fundamentally similar, both seeing the subject in secret without themselves being seen, and Crusoe is confronted with that contradiction, the secret of his Christian premises now laid bare.

In Robinson Crusoe, God cannot tolerate repetition-any exposure of the historical continuity with the figuration of the devil (demonic mystery) or of the tautology of natural law, positing a thing that we can know in the first instance, objectively, before anything else is given (Platonic responsibility). Moreover, any symmetrical "form of reciprocity" between the Christian subject and God must give way to asymmetrical devotion (Derrida 1995, 101), which then secretly effaces the moment of its own inception. God is all-seeing and immortal, yet I am not; he sees me but I cannot see him; the devil, who is not God, can see me in secret like God but can repent just as I can; all-powerful God cannot slay the devil. God must dissolve reciprocity in secret, and Friday's crime is speaking the secret aloud, and thus Defoe's literary mobilization of Christian doctrine is fatal to the integrity of that doctrine. To repair the situation, Crusoe sends Friday away while he prays to God for a means of convincing Friday to worship Christ, but, strangely, Defoe never represents Friday's passage from nonbelief to belief "on-stage," nor does Friday provide much input during his conversion. Presumably, Friday has 
been left to discover his own trembling secret, to develop his soul in an encounter with God, who sees without being seen, in secret from Crusoe. But just as the novel fails to represent the moment of conversion itself, it also fails to consolidate Crusoe's authority as both narrator and Christian colonizer. $^{9}$ This lacuna is partly attributable to the epistolary format in which Crusoe's thoughts are rendered after the shipwreck. However, the fact that Crusoe's own moral and religious doubts find concrete expression in his diary itself draws attention to Friday's absence: without the explicit benefit of intellectual struggle, Friday has arguably become a "better" Christian than Crusoe himself. On first glance, this absence of interiority is perfectly consonant with the colonial project, readable as a Deleuzian "mechanical" repetition of the original white, Christian explorer, absent any sustained intellectual inquiry. However, the net result of this absence is to leave the reader with a far more vivid impression of the astonishing challenge that Defoe has permitted Friday to mount against the moral and natural legitimacy of Christianity, a challenge that puts Christianity into interpenetrative dialogue with colonialism as an economic framework driven by self-interested necessity. The narrative is unable to accommodate the plenitude of Friday's religious conversion, dramatizing the gap between his intellectual rigor, prior to his conversion, and the "reformed" subject whose ability to engage the topic of religious faith has vanished as the direct result of narrative and, thus, colonial necessity. In other words, the text is obliged to make Friday's religious conversion a narrative fait accompli to serve the needs of colonialism.

\section{The secret of sacrifice}

Taking Defoe's novel on its own, one might be forgiven for reducing Friday's queries to nothing but the detritus of a prelapsarian ontology whose naïveté is happily and organically consumed by Christian theology. Considering the novel together with Coetzee's Foe, however, complicates our understanding of these queries. Where Defoe's Crusoe uses a journal to narrate his stay on the island in exhaustive detail, Coetzee's Cruso scorns the written word in favor of his own memory, displaying almost nothing of the explicitly Christian devotion that saturates Robinson Crusoe's account of his life and times on and off the island:

"If Providence were to watch over us," said Cruso, "who would be left to pick the cotton and cut the sugar-cane? For the business of the world to prosper, Providence must sometimes wake and sometimes sleep, as lower creatures do." He saw that I 
Jay Rajiva

shook my head, so went on. "You think I mock Providence. But perhaps it is the doing of Providence that Friday finds himself on an island under a lenient master, rather than in Brazil, under the planter's lash, or in Africa, where the forests teem with cannibals. Perhaps it is for the best, though we do not see it so, that he should be here." (F 23-24)

This critique of Christian divinity is a far cry from Defoe's Crusoe, who insistently places Providence as not only beyond human understanding but also as ceaselessly and actively concerned with human affairs. ${ }^{10}$ Instead, Coetzee's Cruso willingly compares God to lower creatures, creating an insupportable repetition in Christian thought, which amounts to a heresy. Christianity is deeply implicated in the system of production whereby Friday, "a slave and then a castaway," has, in Susan Barton's words, been stripped "of his childhood and consigned to silence" (F 23). If Cruso believes that Providence must slumber in order for the "business of the world to prosper," such a disavowal registers the hypocrisy of religious conversion, since it is precisely Robinson Crusoe's missionary zeal that converts Friday into a docile body within a capitalist framework; the image evokes the eighteenth-century plantation economies of the Caribbean, largely driven by the production of sugar and cotton. Coetzee's Cruso frames Providence as necessarily favoring some people over others, casually noting that Friday's subordinate status on the island is preferable to "the planter's lash" in Brazil or the supposed "cannibals" of an undifferentiated Africa. The latter image, of course, anticipates the Friday of Robinson Crusoe, who openly participates in a culture of cannibalism; to Crusoe's queries he responds: "Yes, my nation eat mans too; eats all up" (RC 164). Coetzee tethers the investigation into Friday's silence specifically to a moment when the extent of divine (Christian) influence is under intense scrutiny; having previously considered Friday "in all matters a dull fellow," giving him "little more attention than [she] would have given any house-slave in Brazil," Barton's response to Friday evolves into "the horror we reserve for the mutilated" (F 24). Yet this evocation of an untold story is itself the product of a story that Robinson Crusoe must also, in its turn, leave untold: the mutual constitutive relationship of Christianity and colonial hegemony.

In this passage on Providence, we can perceive a Crusoe "in waiting," the colonial explorer of Defoe's novel who will eventually subdue and convert Friday to Christianity. However, Coetzee's novel suspends the advent of this figure by keeping two issues at the forefront of the narrative: 
the duty toward individuals such as Friday, and the mystery of his missing tongue. The question of duty gestures to ethical responsibility in the Platonic, rational sense, while the missing tongue testifies to demonic irresponsibility, without endings or beginnings. Only by incorporating (in the Derridean sense elaborated above) these issues into a Christian notion of ethics can Defoe's Crusoe come into being as a legitimate representative of colonial authority. Rather than a disinterested, inconstant presence who "must sometimes wake and sometimes sleep," Providence in Robinson Crusoe is a God who watches everything in secret, holding the subject in the trembling terror of the gaze that the subject can never confront eye to eye. In Foe, by contrast, the circuit of incorporation is revealed and, by that revelation, disrupted.

If God cannot tolerate repetition of himself, how does sacrifice replace that repetition with ontological certainty? Through the abjection of accepting sacrifice's necessity. Derrida takes up the biblical problem of God's demanding Abraham to sacrifice his son Isaac, without God's providing any justification for the demand. At the scene of what he thinks will be an animal sacrifice, Isaac wonders where they will find a sacrificial lamb, and Abraham replies, "God will provide a lamb" (Derrida 1995, 59). Though he does not lie, as Derrida notes, he keeps a secret by saying nothing in his response about God's demand, and thus "transgresses the ethical order." Isaac's deliverance comes precisely when Abraham has mentally given over his son to sacrifice: in the moment when he acquiesces in thought to killing the son he loves, forsaking the ethical relation to his family for the absolute interiority of the secret fulfillment of God's wish, God relents and spares Isaac's life. Abraham's sacrifice of his son in thought is the repetition that both anticipates and negates its material enactment. In accepting the thought of killing his son, Abraham anticipates the actual moment when it will happen, but this willingness to commit mental filicide is exactly what prompts God to spare Isaac's life. To be ethical, to refuse to kill his son even in thought, would render the Christian subject irresponsible to God.

It is not accidental that in instructing Friday on the teachings of Christianity, Defoe's Crusoe mentions that "our blessed Redeemer took not on Him the nature of angels, but the seed of Abraham" (RC 168), prefiguring a later scene in which Friday, thinking that Crusoe means to send him back to his own people, asks Crusoe to kill him instead, speaking with such tearful conviction that Crusoe decides not to send him away. Defoe's Friday thus replays the dilemma of Abraham, offering himself up as absolute sacrifice to an inscrutable superior (Crusoe) who 
Jay Rajiva

withdraws his command only at the moment when Friday has sacrificed by acquiescing of his own accord, without rancor, expecting nothing in return. In Foe, this withdrawal cannot occur, as Friday remains unloved and therefore - if, as Derrida maintains, one can only sacrifice what one loves, or what one truly values - remains unavailable for sacrifice within the symbolic order of Christianity. ${ }^{11}$ The narrative consistently precludes sympathy for Friday, rigidly adhering to Barton's focalization, the colonial slant of which renders it epistemically impossible for her to understand Friday. We get no sustained intersubjective engagement between Friday and Barton, and each attempt to locate meaning in Friday's actions and gestures ends in failure. When Barton provides two sketches of how Friday might have lost his tongue, for instance, and asks Friday to indicate which of them is true, he merely offers a "vacant" (F 69) stare, forcing her to give up the endeavor. When Barton accompanies his flute-playing and dance with music, Friday persists in the same tune that constitutes "no pleasing counterpoint" (97), leaving her to wonder, in the end, whether Friday can even hear her. The slate that Barton and Foe use to teach Friday to read proves useless, as Friday returns the slate to them marked with nothing but rows of unblinking eyes, the naked attempt to impose their will on the colonized other staring back at them, but without a human frame of reference. Friday never speaks, declares his humanity, or enacts a human relation to which Barton can ascribe any positive meaning. Friday's body is impenetrable to understanding and, again, to sacrifice, its status as persistent non-response a constant source of frustration to Susan Barton: “Oh, Friday, how can I make you understand the cravings felt by those of us who live in a world of speech to have our questions answered!" (79). In Barton's many attempts to imagine and recreate Friday's life, his interiority, and his desires, repetition becomes an aporia; stripped of structure and reiteration, each repetition founders and degenerates into "mere congeries of fragmented forms" (Casey 1975, 255). Never answering Barton's questions, Friday remains a being whose negation of the sacrificial secret of Christianity means that his death will only ever be a murder, not a sacrifice.

\section{Foe of the Christian heart}

That Coetzee's Crusoe narrative appeared at the height of apartheid oppression has informed much of its reception. Understanding Foe as deeply engaged with "the powerful silence which is the price of our cultural achievements" (2004, 67), Derek Attridge also sees Coetzee as having, to some degree, "abused his privileges as a member of the white 
elite in addressing not the immediate needs of his time but a mystified human totality" (71). In sum, Attridge argues that the novel investigates its (and Coetzee's) relation to the literary canon in an attempt to participate "in the struggles of those who have been silenced" (72) along lines of race, class, and gender. Correspondingly, Kwaku Larbi Korang rejects what he perceives as the "romance of an abstract and universal textuality" (1998, 183 ) in the figure of Friday. Most polemically, Ngugi wa Thiong'o (1993) has charged Coetzee with retreating from the brutal political realities of an apartheid system that had already triggered the declaration of the State of Emergency. Coetzee's Friday, Ngugi avers, "has no tongue, no voice, no language, and hardly any energy" $(1993,53)$. By contrast, Jarad Zimbler (2004) has emphasized the importance of reading Coetzee in the context of the specific publishing history of Foe. As Zimbler notes, the Ravan Press edition of Foe, part of a book series funded by the same Staffrider magazine whose urban Marxist outlook provided a powerful forum for young black writers to chronicle the daily experience of apartheid, placed the book squarely alongside explicitly political black South African output. In the Ravan Press book blurb, Friday is a "mute negro," the prisoner of an island society of "stone terraces above bleak and empty beaches" whose "rules are strict and simple: survival, industry, order. Cruso is master and Friday is slave"; the blurb ominously hints of "battle lines" being drawn between Cruso and Barton, to which the "silent Friday" is the only witness (Zimbler 2004, 51). ${ }^{12}$

Shifting somewhat from the body of criticism that approaches Foe along the axis of direct political engagement, I read the novel as the product of an author for whom it was impossible, during the apartheid era, "to deny the authority of suffering and therefore of the body" (Coetzee 1992a, 248). If we read Coetzee's novel against Defoe's, this bodily suffering consistently takes place both within a tacitly Christian framework and in the context of a disavowed notion of grace that dramatizes the author's own ambivalent relationship to Christian discourse (discussed above). Particularly telling is Coetzee's equivocating remark that he is "not a Christian," or "not yet" (250). The ambivalence of Coetzee's "not yet" is entirely apposite in a discussion of Friday's place within and between projects of Christian conversion: Foe, in this sense, is the metafictional "not yet," the moment before Christianity becomes the disavowed heart of the colonial enterprise.

For Derrida, the heart is the dwelling-place of secrecy in the Christian self. Removed from all exteriority, the secret must be learned "by heart" without any "semantic comprehension" $(1995,97)$ : this is the 
Jay Rajiva

very essence of devotion to God. Thus, Abraham's willingness to kill his son is not a lesson, nor can we incorporate it into a calculus of ethics without violating the excess of what that willingness must mean before only God, and no other authority. Ethics, expressed as public discourse, murders devotion to God, which is before and above all other duties; we might even say that by speaking his secret aloud, Abraham would murder God. Properly formulated, one's devotion to God tenders the secret of God only to the heart:

The heart will thus be, in the future, wherever you save real treasure, that which is not visible on earth, that whose capital accumulates beyond the economy of the terrestrial visible or sensible, that is, the corrupted or corruptible economy that is vulnerable to moth, rust, and thieves. That does more than imply the pricelessness of celestial capital. It is invisible. It doesn't devalue, it can never be stolen from you.

What the heart contains, then, is invisible, incorporeal, immutable; it defies quantification or exchange; it remains impregnable to theft or loss of value; it cannot be debased or cheapened by any means because it is never intelligible as an exteriority. The heart thus inaugurates the secret as paradox: if spirituality is now in-dwelling, secrecy becomes meaningless as a signifier, because God, the arbiter of the secret, sees everything, even that which one wants to keep secret. The locus of the secret is divinity within me, something that is irreducibly secret and unavailable to others, yet in order to keep this secret in my heart, I must trace a limit between exteriority and God, who by definition can never be reducible to limits. But God's secret resides in me, with my consciousness of him as both proof and precondition of the material exterior.

Tellingly, Derrida's consideration of the heart turns on a question in the form of a repetition: "Where is the heart? What is the heart?" The heart is the organ that circulates blood through my body, without which I cannot live. Therefore, to speak of displacing my heart is to speak of my death in ordinary terms. Yet according to Derrida, the secret heart is "subtracted from space" (101): that is, elided from temporality through displacement. By transforming into the receptacle of a secret, the heart vacates the body. If, however, we were to refuse the transformation of the heart into the atemporal keeper of the Christian secret, or defer this transplant-as-transformation, we would reveal the presence of the operating table, the presence of the surgical scene itself. Such a scene finds its literary expression, I argue, in Foe. Despairing of ever teaching Friday 
to write, Barton wonders how Friday can "be taught to write if there are no words within him, in his heart, for writing to reflect, but on the contrary only a turmoil of feelings and urges" (F 143). In Friday's own not-yet-Christian heart, she imagines, lies the demon that Christianity must incorporate but then disavow. The terror, however, is that Friday's heart refuses such a surreptitious incorporation. While Robinson Crusoe presents the Christian subject fully at home with God as "the secret hand of Providence" that can "search into the remotest corner of the world, and send help to the miserable whenever He [desires]" (RC 210), Foe refuses the transplant of the heart, returning us to a textual and historical moment prior to the figuration of the heart as the keeper of the Christian mystery. We are thrown back into an ethico-spatial instant between worlds that exposes the formulation of Western, imperialist, and Christian ideology. This exposure necessarily works through the novels in tandem: Foe can stage a critique of Christianity as an ethical framework only through the intertextual conversation it invites with the explicit conversion narrative of Robinson Crusoe. At the center of that conversation, and of the ethical hollowness thus represented in Foe, lies Coetzee's refusal to accept the Christian heart of Defoe's novel.

It is true that, though Coetzee's Friday remains unincorporated into the Christian circuit, he cannot retain autonomy within the narrative's framework of social relations. He cannot protect his own body from the colonial exercise of power, nor can he achieve any state of being in which his subjectivity could find direct expression. Furthermore, making the possibility of an epistemic break from colonial logic impossible, and perhaps even unethical, risks glorifying the insularity and ethical paralysis of the white South African writer. Certainly, such observations are important in precluding any valorization of stalled meaning for its own sake, a type of post-structuralist euphoria in aporia that conveniently effaces real inequalities in representation. ${ }^{13}$ However, I would argue that while Susan Barton may be paralyzed, the novel is not, and this distinction is part of what gives Foe its ethical meaning. In reimagining Robinson Crusoe-what Attridge refers to as "probably Western culture's most potent crystallization of its concern with the survival of the individual, the fundamentals of civilized life, and the dialectic of master and servant" $(2004,70)$-Coetzee casts the reality of apartheid against that which would rather remain secret: the exploitative origins of the imperial project, and the relationship between that exploitation and Christianity as a discursive and ethical framework. Metafictionally, Coetzee thus addresses how Defoe's Crusoe comes into being in "the time of conversion" (RC 10), exhuming the 
Jay Rajiva

unacknowledged ethico-spatial moment before Christianity has subsumed Platonic responsibility and demonic mystery to itself.

As metafiction, Foe continuously performs its concern for the validity of narrative within a broader context, offering narrative as rehearsal, revision, counterfactual, unthought, possibility, and impossibility. It consummates its own destruction on every page, anxiously confesses its sins to other readers and writers, and destabilizes its own narrative memory, even supplanting its narrator with another at the climactic encounter with Friday in his own "space." Finally, it shows author, narrative, and characters in a state of becoming, a state anterior to Robinson Crusoe the published novel. It does this not merely to take us "behind the scenes," so to speak, in a gesture that would risk reinscribing the hegemony of the author but rather to halt us perforce at a historical moment of conversion and contestation. If Robinson Crusoe puts repetition to work to clear the path for what cannot bear repetition (God), Foe destabilizes the negotiation of this work through exposure of Christianity as a clandestine process of incorporation. Susan Barton tells us that she has "a desire to be saved which [she] must call immoderate" ( F 36), and, later, faced with a godlike Foe who haunts her with a woman claiming to be her daughter, Barton sardonically remarks that, "in Mr. Foe's house there are many mansions" (77). As Barton draws the comparison between the author and God, Coetzee gestures to the unspeakable in Christianity, which Defoe's Robinson Crusoe will soon replace by the a priori "significatory matrix of the imperium" (Marais 1996, 68), within which the givenness of Christianity will no longer be available to critique. The trembling mystery is emerging, being "fathered" within the fabric of Coetzee's novel-an emergence represented in relation to an absence, Friday's missing tongue. When Susan Barton hesitantly inquires how Friday lost his tongue, half suspecting Cruso of having cut it out, Cruso replies that "Friday lost his tongue before he became mine" (F 37). Coming on the heels of Barton's confession that she has a desire to be saved, Cruso's reply is fraught with religious significance. Is it Cruso speaking here, or is it the soon-to-be Robinson Crusoe of Defoe's novel? Following this trail, Friday could only ever have become Cruso's by losing his tongue, rendering him the demonic mystery silently constituting the spectral limit of the Christian self, a repetition of the demon. Yet this discussion between Barton and Cruso is possible only in a discursive register that allows its speakers to question God without foreclosure. Robinson Crusoe sublates this questioning to an offstage conversion; Foe leaves it suspended, without resolution. 
The Christian heart is a secret, as Derrida has it, and also the secrecy of a secret: the silence that stretches over the demonic and the Platonic, the unacknowledged components of Christianity's trembling mystery. We spy the rough draft of Daniel Foe's work; we peruse the iterations of what will become Robinson Crusoe; we witness Friday treated as a beast of burden by Cruso and then Barton, whose professed desire "to educate him out of darkness and silence" poorly masks her willingness to "use words as the shortest way to subject him to [her] will" (F 60); and we never hear Friday speak, except at the end of the story, when what we hear, "the sounds of the island" (154), overwhelms the parameters of the novel's narrative. In these acts of readership we stumble into a hitherto sanctified space, disturbing a secret and thereby exposing the economy of sacrifice within which the white colonizer strips the colonized other of agency. As I have argued, this exposure is the meta-work that Foe steadfastly refuses to abandon, the persistent return to the surgical scene, where the newly transplanted heart must now make its primary essence the keeping of the originary secret of incorporation, the a priori that casts out ethical responsibility to the other. I earlier touched upon Derrida's formulation of the dissymmetry, the rupture in reciprocity that enables the Christian subject's relationship to God. Is it not, therefore, characteristic of Coetzee to perform such dissymmetry in the very acts of writing and publishing Foe as a white South African during apartheid? What critics ask of Coetzee is not what he delivers; and Friday's story is not what Daniel Foe will publish. In both cases, reciprocity is denied. To the extent that Foe is a revision of Robinson Crusoe, it is also an acknowledgment of Coetzee's own authorial impotence: in destabilizing Defoe's textual authority, that is, Coetzee cannot help but undermine his own, and the literary act of repetition becomes the means of gesturing toward what these repetitions conceal. Gilles Deleuze has noted that "if exchange is the criterion of generality, theft and gift are those of repetition" $(1994,1)$. Foe, then, is the heart just prior to its reception of the secret of Christianity as incorporative process: illuminating an anterior erasure, Coetzee's theft (the Christian colonizer's theft no longer secret) becomes a gift to the reader.

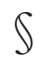

Jay Rajiva is assistant professor of global anglophone literature at Georgia State University. His work has appeared in the Journal of Postcolonial Writing and Research in African Literatures. His forthcoming book, Postcolonial Parabola: Literature, Tactility, and the Ethics of Representing Trauma (Bloomsbury 2017), interrogates the representation of trauma in literature of the late apartheid in South Africa and the partition in South Asia. 
Jay Rajiva

\section{Notes}

1. Foe will be cited as $F$.

2. Mrs. Curren in Age of Iron attempts to find redemption for a life of privilege in an apartheid system as she dies of cancer; in The Master of Petersburg the fictional Dostoevsky, grieving over the death of his stepson, struggles with an ethical obligation to "answer to what he does not expect" (Coetzee 1994, 80); in Disgrace David Lurie seeks forgiveness from the father of Melanie Isaacs, the girl he has raped.

3. Coetzee understands his writing on Tolstoy in these terms, noting that since "the basic movement of self-reflexiveness is a doubting and questioning movement, it is in the nature of the truth told to itself by the reflecting self not to be final" (1992b, 263).

4. See Freud 1939, 102-7. Freud is, however, also focused on how Christian doctrine incorporates its excessive other into a religious tradition that must deny all traces of such incorporation. As an example, he discusses the ritual of communion, which, in its call to Christians to consume and thus incorporate the body of Christ, secretly gestures to older rituals of incorporation through cannibalization. Freud notes that insofar as Christianity "took over from the surrounding peoples numerous symbolic rites, reestablished the great mother goddess, and found room for many deities of polytheism in an easily recognizable guise" (112), it did not maintain the monotheistic rigor of Judaism.

5. Crusoe is the younger brother who eventually acquires wealth and fortune in place of his older brother, who is lost (dead). In this, he represents what Freud sees as the fate of the younger brother in pre-Christian myths, "who, protected by his mother's love, could profit by his father's advancing years and replace him after his death" $(1939,103)$. For Freud, the father is of course God, with the older brother paralleling the Satanic figure in relation to the younger brother as the Christ figure.

6. Robinson Crusoe will be cited as $R C$.

7. See Watt 1957.

8. Another tendency is to fixate almost exclusively on the trajectory of Crusoe's spiritual journey. Focusing on the parallels between Robinson Crusoe and Augustine's Confessions, Lynne Walhout Hinojosa, for example, confines her analysis to Crusoe's own revelations. Arguing that "the troubled relation of Crusoe's Puritan religion and his secular worldly enterprises has been and remains the central quandary of the text" $(2012,644)$, she declines to extend her argument productively to account for Friday's challenge to what she sees as Crusoe's "flawed theology." 
Christianity and Colonialism in Coetzee's Foe and Defoe's Robinson Crusoe

9. In this sense, my argument dovetails with Hinojosa's reading of Crusoe's faulty theology. However, I am less interested in performing an exegetical critique of Crusoe's religious belief than in isolating how this belief dramatizes the incorporative process of Christian colonization. In other words, resistant elements such as Friday must be sublated, after which the process itself is erased, leaving only disavowed traces.

10. Timothy Blackburn links the "simultaneous occurrence of Friday's birth and Crusoe's arrival on the island" to Defoe's insistence on "God's constant role in human life" $(1985,368)$.

11. Similarly, Giorgio Agamben defines homo sacer as one whose "entire existence is reduced to a bare life stripped of every right by virtue of the fact that anyone can kill him without committing homicide" $(1998,183)$.

12. Zimbler (2004) draws a contrast between the Ravan Press blurb, with its Secker and Warburg British analog that made a point of comparing Coetzee to European authors such as George Orwell and Umberto Eco, and the later Penguin edition of Foe, which focused on Susan Barton's "missing” narrative as a feminist project of reclamation.

13. Benita Parry offers an eloquent critique of what she perceives as Coetzee's fascination "with the euphoria of desire unmediated by words," which discursively eliminates any inquiry into "how deprivation inflicts silence on those who are homeless in a hierarchical social world" $(1996,48,46)$.

\section{Works cited}

Agamben, Giorgio. 1998. Homo Sacer: Sovereign Power and Bare Life. Stanford: Stanford University Press.

Asad, Talal. 1993. Genealogies of Religion: Discipline and Reasons of Power in Christianity and Islam. Baltimore: Johns Hopkins University Press.

Attridge, Derek. 2004. “The Silence of the Canon: Foe.” In J. M. Coetzee and the Ethics of Reading: Literature in the Event, 65-90. Chicago: University of Chicago Press.

Blackburn, Timothy C. 1985. "Friday's Religion: Its Nature and Importance in Robinson Crusoe.” Eighteenth-Century Studies 18, no. 3: 360-82.

Casey, Edward. 1975. "Imagination and Repetition in Literature: A Reassessment." Yale French Studies 52: 249-67.

Coetzee, J. M. 1986. Foe. New York: Penguin. 1992a. "Autobiography and Confession." In Doubling the Point: Essays and Interviews, edited by David Attwell, 243-50. Cambridge, MA: Harvard University Press. 1992b. "Confession and Double Thoughts: Tolstoy, Rousseau, and 
Jay Rajiva

Dostoevsky." In Doubling the Point: Essays and Interviews, edited by David Attwell, 251-93. Cambridge, MA: Harvard University Press. 1994. The Master of Petersburg. London: Vintage.

Defoe, Daniel. 1995. Robinson Crusoe. Hertfordshire, UK: Wordsworth.

Deleuze, Gilles. 1994. "Introduction: Difference and Repetition." In Difference and Repetition, 1-27. New York: Columbia University Press.

Derrida, Jacques. 1988. "Signature, Event, Context." In Limited Inc, 1-23. Evanston, IL: Northwestern University Press. 1995. The Gift of Death. Chicago: University of Chicago Press.

Dovey, Teresa. 1998. "J. M. Coetzee:Writing in the Middle Voice.” In Critical Essays on J. M. Coetzee, edited by Sue Kossew, 18-28. New York: Macmillan.

Freud, Sigmund. 1939. Moses and Monotheism. New York: Vintage. Hayes, Patrick. 2006. “'An Author I Have Not Read': Coetzee's Foe, Dostoevsky's Crime and Punishment, and the Problem of the Novel." Review of English Studies 57, no. 230: 273-90.

Hinojosa, Lynne Walhout. 2012. "Reading the Self, Reading the Bible (or Is It a Novel?): The Differing Typological Hermeneutics of Augustine's Confessions and Defoe's Robinson Crusoe." Christianity and Literature 61, no. 4: 641-65.

Hutcheon, Linda. 1988. A Poetics of Postmodernism: History, Theory, Fiction. New York: Routledge.

Korang, Kwaku Larbi. 1998. “An Allegory of Re-Reading: Postcolonialism, Resistance, and J. M. Coetzee's Foe.” In Critical Essays on J. M. Coetzee, edited by Sue Kossew, 180-97. New York: Macmillan.

Marais, Michael. 1996. "The Hermeneutics of Empire: Coetzee's Post-Colonial Metafiction." In Critical Perspectives on J. M. Coetzee, edited by Graham Huggan and Stephen Watson, 66-81. London: Macmillan.

Mcinelly, Brett C. 2003. "Expanding Empires, Expanding Selves: Colonialism, the Novel, and Robinson Crusoe." Studies in the Novel 35, no. 1: 1-21.

Parry, Benita. 1996. "Speech and Silence in the Fictions of J. M. Coetzee." In Critical Perspectives on J. M. Coetzee, edited by Graham Huggan and Stephen Watson, 37-65. London: Macmillan.

Spivak, Gayatri Chakravorty. 1999. A Critique of Postcolonial Reason:Toward a History of the Vanishing Present. Cambridge, MA: Harvard University Press.

Thiong'o, Ngugi wa. 1993. Moving the Centre: The Struggle for Cultural Freedoms. London: Heinemann.

Watt, Ian. 1957. The Rise of the Novel: Studies in Defoe, Richardson, and Fielding. Berkeley: University of California Press.

Zimbler, Jarad. 2004. "Under Local Eyes: The South African Publishing Context of J. M. Coetzee's Foe." English Studies in Africa 47, no. 1: 47-59. 